\title{
The Use of Allogenic Stromal Vascular Fraction (SVF) Cells in Degenerative Joint Disease of the Spine in Dogs
}

\author{
JERZY KEMILEW ${ }^{1}$, ALEKSANDRA SOBCZYŃSKA-RAK ${ }^{2}$, BEATA ŻYLIŃSKA ${ }^{2}$, \\ TOMASZ SZPONDER $^{2}$, BEATA NOWICKA ${ }^{2}$ and BARBARA URBAN ${ }^{3}$ \\ 1 "Kemilew Stem Cells for Animals" Company, Warsaw, Poland; \\ ${ }^{2}$ Department and Clinic of Animal Surgery, Faculty of Veterinary Medicine, \\ University of Life Sciences in Lublin, Lublin, Poland; \\ ${ }^{3} 1$ st Military Clinical Hospital, Lublin, Poland
}

\begin{abstract}
Background/Aim: Stem cells are widely used in regenerative medicine and in clinical practice for the treatment of damaged nerve tissue, myocytes, tendons, and ligaments. The aim of the study was to monitor VEGF levels after the administration of allogenic cellular material (SVF) in the course of treatment of dogs suffering from degenerative joint disease in the spinal region. Materials and Methods: The study was conducted on 10 dogs of both genders, aged between 6 and 13 years in which allogenic stromal vascular fraction of stem cells (SVF) was administered intravenously. The control group was composed of 10 clinically healthy dogs. Before treatment and after 2-and 8-week intervals blood samples were obtained from the study group dogs in order to determine VEGF levels via immunoenzymatic test. Results: in a few days after the therapy, alleviation of pain symptoms and reduction of lameness were noticed. The VEGF level in 2 weeks after the therapy was significantly elevated (median: $38.77 \mathrm{pg} / \mathrm{ml}$ ), while in 8 weeks a decrease was observed (median: $18.37 \mathrm{pg} / \mathrm{ml}$ ). Conlusion: Administration of allogenic stem cells has a positive influence on elevation of the VEGF levels in the blood serum of affected animals as well as their regeneration capacity.
\end{abstract}

The intensive of development of regenerative medicine and gene therapy has contributed to the development of new stem cell treatment methods. The characteristic trait of such cells

This article is freely accessible online.

Correspondence to: Aleksandra Sobczyńska-Rak, Department and Clinic of Animal Surgery, Faculty of Veterinary Medicine, University of Life Sciences in Lublin, 30 Głęboka Str., 20-612 Lublin, Poland. Tel: +48 605889930, e-mail: olsob2@gmail.com

Key Words: Stem cells, Allogenic Stromal Vascular Fraction (SVF), degenerative joint disease, dogs, regenerative medicine. is their potentially unlimited capacity for division and differentiation into various specialised cell types (1-3).

Depending on their differentiation potential, cells can be classified as: totipotent, pluripotent, multipotent, or unipotent $(2,4)$. Stem cells are present at certain stages of an organism's development and at certain organs, and can therefore also be classified as: embryonic (ESC), somatic, mesenchymal, and induced pluripotent stem cells.

Unlike mature, tissue-specific stem cells, ESCs are pluripotent and have the capability to differentiate into any kind of cells. However, despite their considerable promise, the practical usability of ECSs is limited due to potential ethical concerns and the applicable legal regulations. On the other hand, mature, tissue-specific stem cells are immune-compatible and their use is not subject to ethical considerations (5). As demonstrated in recent studies, they are capable of differentiating into cells of the same embryonic origin (multipotency), and under adequate conditions can also display polypotent properties. It is believed that their function is primarily related to the regeneration of damaged and exploited somatic cells. Furthermore, they are tissue-specific and can generate various types of cells with similar properties and embryonic origin (e.g. neural stem cells are able to differentiate into neurons, astrocytes, and oligodendrocytes) (3). The cells can be harvested from bone marrow, blood, nerve tissue, or adipose tissue.

The most common source of stem cells is bone marrow where the populations of hemopoietic stem cells and mesenchymal stem cells (MSC) have been detected $(6,7)$. The cells show a high capacity for proliferation, differentiation into adipocytes, chondrocytes, myeloblasts, and osteoblasts, as well as expression of a variety of surface antigens $(4,8)$. The main problems with obtaining MSCs relate to isolating them and obtaining a sufficient number of cells by way of in vitro cultivation without altering their phenotype.

The presence of MSCs has been described and identified, apart from bone marrow, also in tissue niches of skin, muscles, bones, lungs, liver, blood vessels, and peripheral blood (8). 
They are activated by proinflammatory inductors and inhibit proinflammatory mediators. Proinflammatory mediators stimulate MSCs to secrete prostaglandin which impacts the specific phenotypic transition of proinflammatory M1 macrophages to anti-inflammatory M2 macrophages. They also stimulate MSCs to secrete anti-inflammatory protein TNF- $\alpha$ which inhibits the production of proinflammatory mediators (9). Said reactions allow MSCs to take part in the process of inhibiting the inflammatory response and to stimulate, with the produced cytokines and growth factors, regeneration of damaged tissue $(6,9,10)$.

An alternative source of mesenchymal stromal stem cells is provided by adipose tissue. Similarly to bone marrow, it is of mesodermal origin and contains heterogenic populations of stromal cells. An additional advantage of using adipose tissue over bone marrow is its significantly better availability and therefore the possibility of obtaining larger quantities of cells $(5,6)$.

The first method of isolating cells from adipose tissue was developed in the 1960s by Rodbell and Jones (11) and entailed homogenization of rat fat. Currently, adipose tissue is usually obtained by liposuction or surgically (11).

Adipose-derived stem cells (ASC or ADSC) have the ability to differentiate into adipocytes, osteocytes, chondrocytes, and muscle cells, they also show high angiogenic potential, both in vitro and in vivo (12). In the presence of appropriate growth factors, ADSCs also show the capacity to transdifferentiate into cells of other origins neurogenic, transhepatic, pancreatic, and haematopoietic. The immunological phenotype of human ADSCs is similar to that of bone marrow stem cells (13).

Similarly to bone marrow, adipose tissue is characterised by mesodermal origin and contains populations of stromal vascular fraction cells (SVF), with the added benefit of better availability. The SVF shows high heterogeneity and contains, apart from stem cells, also leukocytes, mastocytes, fibroblasts, pericytes, endothelial cells, and adipocyte precursors (14).

SVFs are widely used in regenerative medicine due to their ability to differentiate into the cells of damaged tissues and organs. An important role in this process is played by their ability to produce hormones, growth factors stimulating cell growth, interleukins $(1,15,16)$, and extracellular matrix proteins $(16,17)$. The main growth factors participating in the initiation and multiplication of ADSCs in the course of regeneration include transforming growth factor beta (TGF$\beta$ )-, platelet-derived growth factor (PDGF), fibroblast growth factor (FGF), and - vascular endothelial growth factor (VEGF) responsible for angiogenesis (18). Moreover, growth factors are induced by inflammatory cells, i.e. macrophages occurring particularly in chronic conditions, and showing chemotactic effects on pluripotent cells. The described abilities increase the regenerative potential of ADSCs and their possible clinical applications in the treatment of damaged nerve tissue, myocytes, tendons, and ligaments in cases of $e . g$. denervation $(7,15)$.

Stem cell-induced angiogenesis, i.e. the formation of new blood vessels, is the basis of processes with considerable physiological and pathological significance. The most important role in this context is attributed to VEGF. It has been demonstrated to also mediate the survival of hematopoietic stem cells, nerve cells, neuronal stem cells, and lymphocytes, as well as to influence the differentiation of megakaryocytes and dendritic cells. Moreover, VEGF induces neurogenesis, through which endothelial cells are stimulated and neurotrophic factors are released (7).

A therapy involving an autological stem cell transplant requires the performance of surgery or liposuction under general anaesthesia. Due to the age of the animals (6-13 years) and the owners' concerns with regard to sedation, we opted for treatment entailing the use of allogenic stromal vascular fraction cells (SVF) obtained from the fat of young dogs - donors.

The goal of the conducted study was to monitor VEGF levels after the administration of the allogenic cellular material (SVF) in the course of treatment of dogs suffering from nervous symptoms in the form of ataxia and limb paresis of various degrees, caused by degenerative lesions in the spinal region.

\section{Materials and Methods}

The study was conducted on 10 dogs of both genders, aged between 6 and 13 years. The animals were patients of the Department and Clinic of Animal Surgery, University of Life Sciences in Lublin, undergoing treatment for orthopaedic and neurological disorders.

The control group was composed of 10 clinically healthy dogs, in good general condition, aged between 4 and 6 years, which were brought in for sterilisation.

In most of the sick animals, the dominant symptoms included mobility disorders, difficulty in standing up and remaining physiologically upright, as well as pain of varying intensity. Some of the dogs suffered from periodic limb paresis. After orthopaedic and neurological examinations, spine x-rays were taken in all the animals, which confirmed the presence of advanced degenerative lesions in the cervical, thoracic and/or lumbosacral spine.

The intensity of pain suffered by the dogs was measured with the short form of the Glasgow Composite Measure Pain Scale score (CMPS - SF) used in behavioural assessment of sensory pain, and the Simple Descriptive Scale (SDS), which allows classification of pain on a five-tier scale.

Due to the act that none of the currently available methods of pain assessment allows a complete diagnosis and evaluation of chronic pain intensity, apart from employing the pain measurement scale, it was also necessary to conduct detailed interviews with the owners. Its purpose was to verify whether any changes could be observed in the animals' behaviour that would suggest the presence of pain (19). In the conducted study, the intensity of pain was evaluated on the following descriptive scale (SDS): no pain, mild, moderate, severe, very severe (Table I). 
Table I. Description of the study group.

\begin{tabular}{|c|c|c|c|c|}
\hline No & $\begin{array}{l}\text { Breed, gender, } \\
\text { age in years }\end{array}$ & $\begin{array}{l}\text { Clinical } \\
\text { symptoms }\end{array}$ & $\begin{array}{l}\text { Radiological } \\
\text { diagnosis }\end{array}$ & Pain \\
\hline 1. & $\begin{array}{l}\text { Alaskan malamute }+ \text {, } \\
\text { age13 }\end{array}$ & $\begin{array}{l}\text { Mobility disorders, periodic rump } \\
\text { paresis, proprioceptive deficits }\end{array}$ & $\begin{array}{l}\text { Degeneration of intervertebral } \\
\text { discs and narrowing at L3/L4/L5 }\end{array}$ & +++ \\
\hline 2. & $\begin{array}{l}\text { German Shepherd } \hat{\partial} \text {, } \\
\text { age } 6\end{array}$ & $\begin{array}{l}\text { Not putting load on the right pelvic limb and } \\
\text { overall weakness of hindlimb muscles, } \\
\text { difficulty standing up and moving around }\end{array}$ & $\begin{array}{l}\text { Narrowing and wedge-like shape of the } \\
\text { intervertebral space at L7/ sacral bone }\end{array}$ & ++++ \\
\hline 3. & Hovawart + , age 9 & $\begin{array}{l}\text { Unstable gait, neurological defects, } \\
\text { mobility disorders }\end{array}$ & $\begin{array}{l}\text { Degeneration of intervertebral } \\
\text { discs L6/L7 }\end{array}$ & ++++ \\
\hline 4. & Cane Corso $\widehat{\partial}$, age 6 & $\begin{array}{l}\text { Lameness and periodic paresis } \\
\text { of the left thoracic limb }\end{array}$ & $\begin{array}{l}\text { Narrowing of the intervertebral } \\
\text { space Th10/Th11 }\end{array}$ & ++++ \\
\hline 5. & Mixed $\delta$, age 6 & $\begin{array}{l}\text { Flaccid paralysis of the hindlimbs, } \\
\text { proprioceptive deficits }\end{array}$ & $\begin{array}{l}\text { Degeneration of intervertebral } \\
\text { discs L4/L5/L6 }\end{array}$ & + \\
\hline 6. & $\begin{array}{l}\text { German Shepherd } \partial \text {, } \\
\text { age } 11\end{array}$ & Stiff gait, mobility disorders & Spondylosis deformans Th12-L7 & ++ \\
\hline 7. & Mixed $\circ$, age 8 & $\begin{array}{l}\text { Periodic pelvic limb paresis, } \\
\text { proprioceptive deficits }\end{array}$ & $\begin{array}{c}\text { Degeneration of intervertebral } \\
\text { discs L5/L6/L7 }\end{array}$ & ++ \\
\hline 8. & Weimaraner $\hat{\delta}$, age 7 & Incoordination of thoracic limbs & Narrowing of the intervertebral space $\mathrm{C} 4 / \mathrm{C} 5$ & +++ \\
\hline 9. & Mastiff, 3 , age 6 & $\begin{array}{l}\text { Hindlimb lameness, unstable gait, } \\
\text { unwillingness to stand up }\end{array}$ & Spondylosis deformans L4/L5/L6/L7 & ++ \\
\hline 10. & Mixed $\hat{\partial}$, age 12 & Hindlimb paresis & $\begin{array}{l}\text { Narrowing of the intervertebral gap L3/L4, } \\
\text { lumbar spine degeneration }\end{array}$ & + \\
\hline
\end{tabular}

Pain in the spinal region during the clinical examination (SDS scale): $(-)-$ no pain; $(+)-$ mild pain; $(++)-$ moderate pain; $(+++)-$ severe pain; $(++++)$ - very severe pain.

In the studied group of animals, despite the early administration of pharmacological treatment with anti-inflammatory drugs or physiotherapeutic treatment, the desired therapeutic effects were not observed and the health improvement was only temporary. Therefore, a decision was reached to treat the patients with allogenic stromal vascular fraction cells (SVF).

Method of isolating cells. Adipose tissue material for the purposes of isolating stem cells was harvested from female dogs aged between 6 months and 2 years. The donors underwent general clinical examinations. Blood tests were performed including blood cell count and 16 biochemical parameters were measured, as well as tests for the presence of vectorial diseases.

Adipose tissue enclosing the broad ligament of the uterus was harvested during sterilisation procedures and placed in a sterile container containing $25 \mathrm{ml}$ of $0.9 \% \mathrm{NaCl}$. The containers were transferred to a specialised laboratory: "Kemilew Stem Cells for Animals" in a transport container maintaining the temperature at $4^{\circ} \mathrm{C} \max$.

The isolation of stromal vascular fraction (SVF) stem cells was performed in accordance with the guidelines for sterile laboratory work. The adipose tissue material was rinsed with buffered PBS (Dulbecco's \& Phosphate Buffered Saline) and minced mechanically until fragments of approx. 1-2 mm were obtained. The obtained material was once again rinsed with PBS with the infranatant removed using a pipette. The minced adipose tissue was subsequently subjected to enzymatic digestion with the use of type I collagenase (Collagenase from Clostridium histolyticum for general use, Type I, 0.25-1.0 FALGPA units/mg solid -125 CDU/mg solid - Sigma Aldrich, Darmstadt, Germany) at a concentration of $0.04-0.09 \%$, for $60 \mathrm{~min}$ at $36^{\circ} \mathrm{C}$. After the incubation, collagenase was neutralised with $10 \%$ DMEM. The suspension was centrifuged $(700 \times g$ for $15 \mathrm{~min})$, resuspended in PBS, and once again centrifuged $(700 \times g$ for $15 \mathrm{~min})$.

After centrifugation, the cells were suspended in PBS. The obtained suspension was filtered through a $100 \mu \mathrm{m}$ and $70 \mu \mathrm{m}$ cell strainer to remove impurities. The filtered cell suspension was centrifuged $(700 \times g$ for $15 \mathrm{~min})$.

The final preparation of the obtained SVF suspension for subsequent clinical application entailed quantitative and qualitative evaluation of the cell suspension and microbiological assessment. The percentage of living cells was determined with the use of fluorescence microscopy after ethidium bromide staining. Cell concentration was determined in a Fuchs-Rosenthal chamber after trypan blue staining. The microbiological assessment of the obtained cell suspension was performed on three media:

1. BHI broth, volume of tested solution: $0.5 \mathrm{ml}$, incubation at $38^{\circ} \mathrm{C}$, readout after $24 \mathrm{~h}$.

2. Columbia medium, volume of tested solution: $0.6 \mathrm{ml}$, incubation at $38^{\circ} \mathrm{C}$, readout after $48 \mathrm{~h}$.

3. MacConkey's medium, volume of tested solution: $0.6 \mathrm{ml}$, incubation at $38^{\circ} \mathrm{C}$, readout after $48 \mathrm{~h}$.

The obtained suspension of SVF cells was placed in sterile $4 \mathrm{ml}$ syringes. The cell concentration was $20 \times 10^{6} / \mathrm{ml}$. The dosage was established at $1 \mathrm{ml} / 10 \mathrm{~kg} \mathrm{bm}$. i.e. $2 \times 10^{6} / 1 \mathrm{~kg}$ of body mass, based on reports published by other authors and our own clinical observations $(10,15,20,21,22)$.

The doses were prepared in sterile syringes, placed inside a transport box with a cooling insert maintaining the temperature at $4^{\circ} \mathrm{C}$ max. and sent by courier mail to the laboratory of the Department and Clinic of Animal Surgery at the University of Life Sciences in Lublin. 
The allogenic stromal vascular fraction (SVF) was administered intravenously to the study group animals.

Prior to the treatment, as well as 2 and 8 weeks after SVF administration, blood samples were drawn from the study group of animals to obtain serum for immunoenzymatic tests. Blood samples were also drawn once from the control group of animals.

After centrifugation, the obtained blood serum was stored at the temperature of $-75^{\circ} \mathrm{C}$ before conducting the assays. The levels of VEGF (Vascular Endothelial Growth Factor) in blood serum of the study and control group animals were determined by ELISA immunoenzymatic assay (Quantikine Canine Immunoassay; R\&D Systems, INC Minneapolis, USA, supplier BIOKOM). The tests were conducted in accordance with the protocol recommended by the manufacturer.

The owners of the animals signed a written consent to the animal's participation in the experiment and an agreement with regard to monitoring the dog's condition after stem cell administration. The owners also agreed to bring the animals in for check-up on specific dates and consented to the dogs' blood being drawn 2 and 8 weeks after the procedure.

The research procedures were consistent with the protocol and approved by the Local Ethics Committee No. II in Lublin (permit no. $26 / 2015,28.04 .2015$ to conduct experiments on animals; experiments on animal tissues and organs).

A statistical analysis was conducted to determine whether significant correlations could be identified between the level of VEGF in blood serum of the test group of animals and the control group, as well as whether statistically significant differences were observed in VEGF levels after 2 and 8 weeks from administering the SVF therapy.

To ensure the choice of adequate test for the purposes of the comparisons, the normal distribution of the obtained quantitively values relative to the Gaussian function was verified. The Kolmogorov-Smirnov test was used for this purpose. The analysed traits did not show normal distribution, hence in all further calculations the non-parametric Mann-Whitney test was used when comparing two groups of animals (test function designation - "Z") and the Kruskal-Wallis test when comparing larger numbers (test function designation - "H").

\section{Results}

A description of the study group of animals, including results of radiological examinations and clinical symptoms is provided in Table I.

After the intravenous administration o allogenic stem cells (SVF), all study groups of animals showed signs of significant improvement. Within one week after the injection, considerable alleviation of pain symptoms was observed. In six animals, complete absence of pain was reported by the owners and confirmed in the course of a clinical examination conducted one week after the SVF injection. In two cases a significant reduction of lameness was observed, although the animals experienced slight pain during the clinical examination conducted 2 weeks after the therapy. Based on the observation and the owners' reports, the overall condition of the animals improved in the entire study group after 3-4 weeks from the treatment and the effects persisted throughout the subsequent 6-month observation period.
Table II. VEGF levels assayed by immunoenzymatic tests at the respective time points.

\begin{tabular}{lrcr}
\hline No. & \multicolumn{3}{c}{ VEGF pg/ml } \\
\cline { 2 - 4 } & Time point 0 & Time point 1 & Time point 2 \\
\hline 1 & 9.49 & 39.42 & 17.37 \\
2 & 6.12 & 37.35 & 10.21 \\
3 & 9.37 & 129.8 & 39.42 \\
4 & 10.37 & 65.94 & 21.69 \\
5 & 9.37 & 34.41 & 6.12 \\
6 & 10.81 & 112.62 & 25.94 \\
7 & 18.79 & 35.06 & 11.12 \\
8 & 11.26 & 34.41 & 18.62 \\
9 & 10.37 & 78.62 & 30.22 \\
10 & 8.09 & 38.13 & 18.12 \\
\hline
\end{tabular}

Time point 0 - before treatment; Time point 1 - two weeks after treatment; Time point 2 - eight weeks after treatment.

The results of the immune-enzymatic determinations of VEGF levels in the respective study periods are presented in Table II. The VEGF values in the control group oscillated between 0.1 and $10.37 \mathrm{pg} / \mathrm{ml}$ (median: $5.7 \mathrm{pg} / \mathrm{ml}$ ). The median of the serum VEGF levels in the blood collected from the study group of animals on the day of the treatment, prior to administration of the cell therapy (Time point 0 ) was $9.93 \mathrm{pg} / \mathrm{ml}[6.12-18.79 \mathrm{pg} / \mathrm{ml}]$. These levels were significantly higher than those in the control group $(* * * p<0.001)$. The VEGF levels monitoring in time $(2$ and 8 weeks after the therapy) revealed significantly elevated VEGF levels 2 weeks after the SVF injection (Time point 1) when it oscillated between 34.41 and $129.9 \mathrm{pg} / \mathrm{ml}$ (median: $38.77 \mathrm{pg} / \mathrm{ml}$ ). At 8 weeks after the treatment (Time point 2), a statistically significant decrease in serum VEGF levels was observed - median $18.37 \mathrm{pg} / \mathrm{ml}$, although they still remained statistically higher than the VEGF levels observed in the control group $(* p<0.05)-$ detailed results are presented in Table III.

\section{Discussion}

Regenerative medicine is an interdisciplinary field of medicine concerned with the repair and regeneration of damaged tissues and organs with the use of stem cells.

Adipose tissue is a good source of mesenchymal stem cells (MSC). The autologous origin of such cells and their ability to differentiate into lines of mesodermal origin as well as other primordial cell layers, renders them an ideal material for cellular therapy (22). It has been demonstrated that the therapeutic effects of MSCs come in two distinct forms: immunomodulation and trophic activity. The immunoactivity of these cells is mediated by bioactive particles and through cell-to-cell contact, and can involve dendric cells, B and T 
Table III. Comparison of blood serum VEGF levels in the respective examinations.

\begin{tabular}{|c|c|c|c|c|c|c|}
\hline \multirow[t]{2}{*}{ Group } & \multirow[t]{2}{*}{$\mathrm{N}$} & \multicolumn{5}{|c|}{ VEGF pg/ml } \\
\hline & & Median & Min & Max & Mean & SD \\
\hline Control & 10 & 5.7 & 0.1 & 10.37 & 4.91 & 3.27 \\
\hline \multirow[t]{2}{*}{ Time point 0} & \multirow[t]{2}{*}{10} & \multirow[t]{2}{*}{9.93} & \multirow[t]{2}{*}{6.12} & 18.79 & \multirow[t]{2}{*}{10.4} & \multirow[t]{2}{*}{3.29} \\
\hline & & & & $(* * *) \quad p<0.001$ & & \\
\hline Time point 0 & 10 & 9.93 & 6.12 & 18.79 & 10.4 & 3.29 \\
\hline \multirow[t]{2}{*}{ Time point 1} & \multirow[t]{2}{*}{10} & \multirow[t]{2}{*}{38.77} & \multirow[t]{2}{*}{34.41} & 129.8 & \multirow[t]{2}{*}{60.57} & \multirow[t]{2}{*}{35.53} \\
\hline & & & & $(* * *) \quad p<0.001$ & & \\
\hline Time point 1 & 10 & 38.77 & 34.41 & 129.8 & 60.57 & 35.53 \\
\hline \multirow[t]{2}{*}{ Time point 2} & \multirow[t]{2}{*}{10} & \multirow[t]{2}{*}{18.37} & \multirow[t]{2}{*}{6.12} & 39.42 & \multirow[t]{2}{*}{19.88} & \multirow{2}{*}{9.99} \\
\hline & & & & $(* * *) \quad p<0.001$ & & \\
\hline Control & 10 & 5.7 & 0.1 & 10.37 & 4.91 & 3.27 \\
\hline \multirow[t]{2}{*}{ Time point 2} & \multirow[t]{2}{*}{10} & \multirow[t]{2}{*}{18.37} & \multirow[t]{2}{*}{6.12} & 39.42 & \multirow[t]{2}{*}{19.88} & \multirow[t]{2}{*}{9.99} \\
\hline & & & & $(* * *) \quad p<0.001$ & & \\
\hline Time point 0 & 10 & 9.93 & 6.12 & 18.79 & 10.4 & 3.29 \\
\hline \multirow[t]{2}{*}{ Time point 2} & \multirow[t]{2}{*}{10} & \multirow[t]{2}{*}{18.37} & \multirow[t]{2}{*}{6.12} & 39.42 & \multirow[t]{2}{*}{19.88} & \multirow[t]{2}{*}{9.99} \\
\hline & & & & $(*) \quad p<0.05$ & & \\
\hline
\end{tabular}

cells, and killer cells. On the other hand, trophic effects are elicited by factors produced by MSCs, which inhibit apoptosis, stimulate angiogenesis by secreting VEGF as well as mitosis and differentiation of tissue-intrinsic reparative or stem cells (23). A unique and clinically important quality of MSCs is their capacity for immunomodulation of the patient's immune system by inhibiting the response to histocompatibility antigens. MSCs administered to a recipient with HLA (Human Leukocyte Antigen), for dogs DLA (Dogs Leukocyte Antigen) incompatibility will reduce the intensity of the recipient's immune response related to the GvHD (Graft versus Host Disease). Due to the above, stem cells can be transplanted not only as autologous but also as allogenic grafts (24). We took advantage of this particular property of the cells and allogenic stromal vascular fraction cells harvested from the fat of young dogs were used therapeutically in the present study.

MSCs can be obtained from a number of sources, but given the relative ease of harvesting cells and applying them clinically, MSCs originating from bone marrow or adipose tissue are most commonly used. A number of studies have confirmed their beneficial effects in the treatment of osteoskeletal injuries where they can ensure the homing of natural or artificial scaffolds implanted when there is a need to complement missing bone of cartilage material $(25,26)$. MSCs are also widely used in aesthetic medicine, orthopaedics, and the treatment of growth disorders, tendinitis, or joint regeneration. In reconstructive medicine, they are commonly used in the treatment of soft tissue defects $(15,27)$.

Cellular therapies have been used in various animal species. Treatment with autologous MSCs harvested from bone marrow proved to be an effective therapy in cases of superficialis digital flexor tendinopathy in horses. The relevant study pertained in particular to horses suffering from flexor tendon injury due to overload. Cells were administered under ultrasound control into the region of the pathological tendon lesions. The therapeutic effects were observed for a period of 3 years. Most horses showed full recovery to the pre-trauma condition already 3 months after the injection, and ultrasound and scintigraphic examinations showed no irregularities. This contrition persisted for a number of years (28).

MSCs have also been used in the treatment of canines suffering from orthopaedic diseases leading to degenerative lesions in the locomotor system due to genetic, traumatic or dietary problems and the animal's obesity. Secondary accompanying symptoms in such cases include inflammation, loss of tendon and ligament elasticity, as well as severe pain. The treatment method of choice is usually pharmacotherapy using non-steroidal or steroidal anti-inflammatory drugs. However, such therapy can only alleviate the symptoms accompanying degenerative processes and can be a considerable burden to patients in an advanced age. Therefore, cellular therapy has been embraced as a safer alternative treatment method $(22,29)$. Nicpoń reported on 
such treatment in a group of 12 dogs suffering from cubital joint degeneration. In that study, autologous stem cells isolated from adipose tissue were grafted into the cubital joint. The patients showed significant improvement, reduced lameness, and considerable alleviation of pain (30).

Adipose stem cells (ASCs) in their physiological state and environment are not particularly active, but after stimulation (e.g. in vitro culture) they can show considerable proregenerative potential (31). A significant advantage of ASCs over other types of cells relates to the fact that laboratory tissue cultures are not necessary to reach the so-called "therapeutic threshold" - i.e. the number of cells sufficient for therapeutic purposes. ASCs are obtained from fat harvested from animals. After adequate enzymatic digestion and centrifugation, the top adipocyte fraction is obtained as well as sedimentation of the stromal vascular fraction (SVF) containing, among other elements, ASCs, progenitor endothelial cells, macrophages, smooth muscle cells, lymphocytes, pericytes, and preadipocytes.

ASCs have been subjected to intensive scientific scrutiny since the beginning of the 21 st century and have been used as the primary source of cells with high regenerative potential and characteristics similar to those of mesenchymal stromal stem cells (22). For this reason, they have been successfully used in regenerative and reconstructive medicine.

The key functions of ASCs include stimulation of angiogenesis, stimulation and transformation of fibroblasts, and mobilisation of endogenic stem cells (28). The same is achieved through the production of cytokines and growth factors: FGF, HGF, TGF- $\beta$, and VEGF, through paracrine stimulation of regenerative processes $(14,31)$. VEGF expression and angiogenesis are part of a process necessary for successful tissue regeneration (32). It has been demonstrated that inhibition of VEGF activity impairs bone formation and expansion of hypertrophic chondrocytes, and completely supresses the formation of new blood vessels (33).

As reported in recent studies, the best effects are obtained when instead of ASCs. stromal vascular fraction cells (SVF) are used. Although their properties in terms of immunomodulation, ant-inflammatory and proangiogenic activity are roughly the same, they nonetheless show higher therapeutic efficacy in comparative studies conducted on animals (34). Moreover, SVF are easier to obtain as they do not require isolation of various types of cells (20).

Studies have also been conducted to determine the correlation between the age of patients from which fat for SVF isolation is harvested and the resulting angiogenic potential. It has been shown that cells isolated from younger donors show better neovascularisation capacity, and therefore higher regenerative potential $(35,36)$.

The results of our own research also suggest that cells isolated from young animals (allogenic graft from adipose tissue harvested in young dogs) had a significant impact by stimulating angiogenesis and production of growth factors, particularly VEGF whose levels increased significantly (34.41-129.8 pg/ml) after 2 weeks from the treatment. VEGF overexpression, relative to the control group as well as to the study group prior to the cell injection, may be considered as evidence for the proangiogenic effects of SVF and the stimulation of regenerative processes in damaged tissues, even 8 weeks after administering the treatment.

Adipose-derived SVF continues to be studied as a potential alternative treatment in orthopaedics, for the regeneration of cartilage, bone, tendon and ligament damage, as well as in the treatment of neurological disorders (37-39).

Cellular therapies with the use of adipose-derived SVF are an element of the primary clinical treatment chosen by American veterinarians due to the fact that can be applied immediately or shortly after processing the material (40). Vet Stem, as a commercial supplier operating since 2004, has been able to isolate SVF for over 8000 domestic animals (40).

The advantage of stem cells isolated from adipose tissue stems from their immunosuppressive and anti-inflammatory properties which are particularly important in chronic inflammatory conditions (41). An important trait for their clinical applications is their ability to accumulate in the tissue repair region. After intravenous administration, they tend to migrate to the damaged regions identified by their inflammatory reaction (26). This property has been used in our own research where the cellular solution was also administered intravenously.

For a dozen or so years, research has been conducted in the context of veterinary medicine with the aim of verifying the effectiveness of cellular therapies. SVF injections were administered to dogs suffering from osteoarthrosis /osteoarthritis of the hip joint. Clinical examinations were conducted $4,8,12$, and 24 weeks after the injection. The researchers have reported a significant reduction in lameness and pain during the orthopaedic examination, and the therapeutic effect persisted for several months (42).

Similar studies have been conducted by Pak et al. who used SVF to facilitate articular cartilage regeneration (39). The cells were injected into knee joints diagnosed with osteoarthrosis/ osteoarthritis. After 3 months, the following factors were evaluated: the visual analogue score (VAS) for pain, function rating index (FRI) and range of motion (ROM). A significant overall health improvement and MRI-verified cartilage regeneration was observed. They have also studied the applicability of SVF in cases of iliac osteoarthrosis/osteoarthritis and head of the femur necrosis (39). Similar results have been reported, i.e. significantly reduced pain and lameness.

Other researchers have also used, similarly to the present study, stem cells obtained from fat by following standard sterilization procedures $(37,38,43)$. Cells were administered intra-articularly in dogs suffering from elbow joint dysplasia and osteoarthrosis/osteoarthritis. The cellular therapy allowed elimination of lameness and pain and resulted in a 
significant improvement of the patients' condition, as verified in the course of a clinical examination $(37,43)$. In observations reported by Kriston-Pal, several dogs showed arthroscopically confirmed side effects in the form of periarticular tissue swelling (43). In our own studies, similarly to the results reported by the aforementioned researchers, a significant reduction in pain and lameness was observed in 6 of the 10 studied animals as early as within days after the treatment, even though a different route of stem cell administration was chosen. Intravenous injection of stem cells had the added benefit of preventing the postinjection swelling of periarticular tissues observed in the study by Kriston-Pal (43).

The processes of cellular regeneration are specific to the region subjected to stem cell activity. The rate of regeneration thereof shows considerable individual discrepancies, e.g.: the regeneration of a damaged cartilage can take up to 2-3 months, even though pain symptoms subside within 2 weeks of the local intraarticular administration of stem cells. Therapeutic effects were observed in $90 \%$ of patients suffering from degenerative diseases, which confirms the high efficacy of the method (44).

Wei et al. have recently demonstrated that the therapeutic effects of ASCs are due to the paracrine effects of the growth factors they secrete. Based on those results, the potential therapeutic applications ASCs in the treatment of spinal cord damage and cerebral stroke have been suggested $(12,45)$.

Similar results were obtained in our study group where elevated VEGF levels were observed after the administration of stem cells. It can be assumed that overexpression of VEGF was significantly conducive to the therapeutic effect observed also in our research.

VEGF affects both the vascular and the nervous system. In vitro, it participates in protecting neurons against the effects of toxic factors such as: hypoxia or oxidative stress. It shows neuroprotective properties, stimulates the growth of new neurons, and increases the perfusion of ischaemic areas (17). Elevated VEGF levels were observed in in vivo studies on rats suffering from ischaemia of the central nervous system. By inducing angiogenesis and restoring oxygen supply in the damaged tissue, VEGF was instrumental in reducing ischaemia and the extent of brain damage $(17,46,47)$.

VEGF plays a vital role, not only in the context of vascularisation, but also in neuron proliferation and development of coordinated vascular and neuronal networks. There is a growing body of evidence to suggest that VEGF is essential to the survival of motor neurons, and improper regulation or decrease in VEGF levels may lead to neuronal degeneration observed in diseases of the nervous system (16, $17,33,46,47)$. However, it remains difficult to ascertain whether its restorative and neuroprotective effects stem from direct effects of VEGF on the nervous system or rather constitute a secondary effect of VEGF-induced angiogenesis and improved cell perfusion in the damaged region $(33,47)$.
Cellular therapy continues to be intensively developed and has the potential to offer a wide range of therapeutic applications, however, the molecular mechanisms entailed in stem cell activity require further, in-depth study.

\section{Conclusion}

The administration of allogenic stem cells resulted in elevation of the VEGF levels in blood serum of sick animals. It can be assumed that the same can affect the organism's regenerative capacity and, in the context of some diseases, inhibit the development of pathological lesions. VEGF overexpression may be considered as evidence for the proangiogenic effects of SVF and the stimulation of regenerative processes in damaged tissues.

\section{Conflicts of Interest}

The Authors have no conflict of interest to disclose regarding this study.

\section{Authors' Contributions}

JK and ASR received the idea; ASR and TS performed the experiments; $\mathrm{BZ}, \mathrm{BN}$ and $\mathrm{BU}$ collected and analyzed data and interpreted results; JK and ASR wrote the manuscript; all Authors corrected and approved the final draft.

\section{References}

1 Bużańska L: Neural stem cells from human cord blood immunocytochemical, physiological and molecular analysis. Postep Biol Kom 4: 667-681, 2006.

2 Gliński Z and Luft-Deptuła D: Stem cells - benefits and failures. Zycie Wet 90: 141-144, 2015. Available at: http://agro.icm. edu.pl/agro/element/bwmeta1 .element.agro-a4f659dd-2cdd4a37-8ec9-8b1a8cd635cf (Accessed June 21 2019)

3 Roszek K and Komoszyński M: Regulation and direction of umbilical cord blood stem cells differentiation and their therapeutic application. Post Hig med Dosw 62: 660-667, 2008. PMID: 19057508.

4 Jezierska-Woźniak K, Nosarzewska D, Tutas A, Mikołajczyk A, Okliński $\mathrm{M}$ and Jurkowski MK: Use of adipose tissue as a source of mesenchymal stem cells. Hig Med Dosw 64: 326-332, 2010. PMID: 20679688.

5 Zuk PA, Zhu M, Mizuno H, Huang J, Futrell JW, Katz AJ, Benhaim P, Lorenz HP and Hedrick MH: Multiline age cells from human adipose tissue: implications for cell-based therapies. Tissue Eng 7: 211-228, 2001. PMID: 11304456. DOI: 10.1089/ 107632701300062859

6 Kulus M, Kulus J, Jankowski M, Borowiec B, Jeseta M, Bukowska D, Brüssow KP, Kempisty B and Antosik P: The use of mesenchymal stem cells in veterinary medicine. Med J Cell Biol 6: 101-107, 2018. DOI: 10.2478/acb-2018-0016

7 Wei Ch, Lin AB and Hung SC: Mesenchymal stem cells in regenerative medicine for musculoskeletal diseases: bench, bedside and industry. Cell Transplantation 23: 505-512, 2014. PMID: 24816447. DOI: 10.3727/096368914X678328 
8 Kuroda Y, Kitada M, Wakao S and Dezawa M: Bone marrow mesenchymal cells: how do they contribute to tissue repair and they really stem cells? Arch Immunol Ther Exp 59: 369-378, 2011. PMID: 21789625. DOI: 10.1007/s00005-011-0139-9

9 Szala S, Wiśniewska E, Matuszczak S and Czapla J: Mesenchymal Stromal Cells. Postepy Hig Med Dosw 68: 12871298, 2014. PMID: 25404618.

10 Schwarz C, Leicht U, Drosse I, Ulrich V, Luibl V, Schieker M and Röcken M: Characterization of adipose-derived equine and canine mesenchymal stem cells after incubation in agarosehydrogel. Vet Res Commun 35: 487-499, 2011. PMID: 21755 422. DOI: $10.1007 / \mathrm{s} 11259-011-9492-8$

11 Rodbell M. The metabolism of isolated fat cells. IV. Regulation of release of protein by lipolytic hormones and insulin. J Biol Chem 241: 3909-3917, 1966. PMID: 4288359.

12 Wei X, Zhao L, Zhong L, Gu H, Feng D, Johnstone BH, March KL, Farlow MR and Du Y: Adipose stromal cells-secreted neuroprotective media against neuronal apoptosis. Neurosci Lett 462: 76-79, 2009. PMID: 19549558. DOI: 10.1016/j.neulet. 2009.06.054

13 Festy F, Hoareau L, Bes-Houtmann S, Péquin AM, Gonthier MP, Munstun A, Hoarau JJ, Césari M and Roche R: Sur face protein expression between human adipose tissue-derived stromal cells and mature adipocytes. Histo-chem Cell Biol 124: 113-121, 2005. PMID: 16032396. DOI: 10.1007/s00418-005-0014-Z

14 Gimble J, Katz A and Bunnel A: Adipose-derived stem cells for regenerative medicine. Circ Res 100: 1249-1260, 2007. PMID: 17495232. DOI: 10.1161/01.RES.0000265074.83288.09

15 Blecker D, Elashry MI, Heimann M, Wenisch S and Arnhold S: new insights into the neural differentiation potential of canine adipose tissue-derived mesenchymal stem cells. Anat Histol Embryol 46: 304-315, 2017. PMID: 28401575. DOI: 10.1111/ ahe.12270

16 Brockington A, Lewis C, Wharton S and Shaw PJ: Vascular endothelial growth factor and the nervous system. Neuropathol Appl Neurobiol 30: 427-446, 2004. PMID: 15488020. DOI: 10.1111/j.1365-2990.2004.00600.x

17 Namiecińska M, Marciniak K and Nowak JZ: VEGF as an angiogenic, neurotrophic, and neuroprotective factor. Postepy Hig Med Dosw 59: 573-583, 2005. PMID: 16407796.

18 Nakagami H, Morishita R, Maeda K, Kikuchi Y, Ogihara T and Kaneda Y: Adipose tissue-derived stromal cells as a novel option for regenerative cell therapy. J Athroscler Thromb 13: 77-81, 2006 PMID: 16224047. DOI: 10.1161/01.ATV.0000190701. 92007.6d

19 Mathews KA, Kronen PW, Lascelles D, Nolan A, Robertson S, Steagall PVM, Wright B and Yamashita K: Guidelines for Recognition, Assessment and Treatment of Pain. JSAP 55: 1-67, 2014. DOI: $10.1111 /$ jsap. 12200

20 Astor DE, Hoelzler MG, Harman R and Bastian RP: Patient factors influencing the concentration of stromal vascular fraction (SVF) for adipose-derived stromal cell (ASC) therapy in dogs. Can J Vet Res 77: 177-182, 2013. PMID: 24101793.

21 Hoffman AM and Dow SW: Concise Review: Stem cell trials using companion animal disease models. Stem Cells 34: 17091729, 2016. PMID: 27066769. DOI: 10.1002/stem.2377

22 Marx C, Silveira MD and Nardi NB: Adipose-derived stem cells in veterinary medicine: Characterization and therapeutic applications. Stem Cell Dev 24: 803-813, 2015. PMID: 25556829. DOI: $10.1089 / \mathrm{scd} .2014 .0407$

23 Caplan A and Correa D: The MSC: an injury drugstore. Cell Stem Cell 9: 11-15, 2011. PMID: 21726829. DOI: 10.1016/ j.stem.2011.06.008
24 Strużyna $\mathrm{J}$ and Pojda Z: Adipose stem cell applications in regenerative medicine. Plast Surg Burns 3: 151-157, 2015. DOI: $10.15374 / \mathrm{ChPiO} 2015015$

25 Bakker De E, Van Ryssen B, De Schauwer C and Meyer E: Canine mesenchymal stem cells: state of the art, perspective as therapy for dogs and as a model for man. Vet Q 33: 225-233, 2013. PMID: 24404887. DOI: $10.1080 / 01652176.2013 .873963$

26 Pojda Z, Machaj E, Kurzyk A, Mazur S, Dębska T, Gilewicz J and Wysocki J: Mesenchymal stem cells. Postepy Biochem 59: 187-197, 2013. PMID: 24044283.

27 Brey EM and Patrick CWJ: Tissue engineering applied to reconstructive surgery. IEEE Eng Med Biol Mag 19: 122-125, 2000. PMID: 11016039. DOI: 10.1109/51.870241

28 Godwin EE, Young NJ, Dudhia J, Beamish IC and Smith RKW: Implantation of bone marrow-derived mesenchymal stem cells demonstrates improved outcome in horses with overstrain injury of the superficial digital flexor tendon. EVJ 44: 25-32, 2012. PMID: 21615465. DOI: 10.1111/j.20423306.2011.00363.x

29 Kiefer KM, Lin K, Fitzpatrick N, Pluhar E, and Conzemius MG: Does adipose-derived stromal cell adjuvant therapy for fragmented medial coronoid process in dogs influence outcome? A Pilot Project. Vet Evid 1: 2-17, 2016. DOI: 10.18849/ ve.v1i4.45

30 Nicpoń JK, Marycz J, Grzesiak A, Śmieszek N and Toker ZY: The advantages of autologus adipose derived mesenchymal stem cells (AdMSCs) over the NSAIDs application for degenerative elbow joint disease treatment in dogs - twelve cases. Kafkas Univ Vet Fak Derg 20: 345-350, 2014. DOI: 10.9775/kvfd. 2013.10105

31 Pikuła M, Langa P, Kosikowska P and Trzonkowski P: Stem cells and growth factors in wound healing. Postepy Hig Med Dosw 69: 874-885, 2015. PMID: 26270514.

32 Sobczyńska-Rak A: The role of VEGF in process of neovasculogenesis. In: Ran, S. (eds): Tumor Angiogenesis. Intech, Rijeka, Croatia. pp. 181-196, 2012. DOI: 10.5772/30233

33 Maharaj ASR and De'Amore PA: Roles for VEGF in adult. Microvasc Res 74: 100-113, 2007. PMID: 17532010. DOI: 10.1016/j.mvr.2007.03.004

34 You D, Jang MJ, Kim BH, Song G, Lee C, Suh N, Jeong IG, Ahn TY and Kim CS: Comparative study of autologous stromal vascular fraction and adipose-derived stem cells for erectile function. Recovery in a rat model of cavernous nerve injury. Stem Cells Transl Med 4: 351-358, 2015. PMID: 25792486. DOI: $10.5966 /$ sctm.2014-0161

35 Aird Al, Nevitt ChD, Christian K, Williams SK, Hoying JB and LeBlanc AJ: Adipose-derived stromal vascular fraction cells isolated from old animals exhibit reduced capacity to support the formation of microvascular networks. Exp Gerantol 63: 18-26, 2015. PMID: 25617825. DOI: 10.1016/j.exger.2015.01.044

36 Shi YY, Nacamuli RP, Salim A and Longaker M: The osteogenic potential of adipose-derived mesenchymal cells is maintained with aging. Plast Reconstr Surg 116: 1686-1696, 2005. PMID: 16267433. DOI: 10.1097/01.prs.0000185606.03222.a

37 Black LL, Gaynor J, Adams C, Dhupa S, Sams AE, Taylor R, Harman S, Gingerich DA and Harman R: Effect of intraarticular injection of autologous adipose-derived mesenchymal stem and regenerative cells on clinical signs of chronic osteoarthritis of the elbow joint in dogs. Vet Ther 9: 192-200, 2008. PMID: 19003780 . 
38 Guercio A, Di Marco P, Casella S, Cannella V, Russotto L, Purpari G, Di Bella S and Piccione G: Production of canine mesenchymal stem cells from adipose tissue and their application in dogs with chronic osteoarthritis of the humeroradial joints. Cell Biol Int 36: 189-191, 2012. PMID: 21936851. DOI: 10.1042/CBI20110304

39 Pak J, Lee JH, Park KS, Park M, Lin-Woo Kang LW and Lee $\mathrm{SH}$ : Current use of autologous adipose tissue-derived stromal vascular fraction cells for orthopaedic applications. J Biomed Sci 24: 1-9, 2017. DOI: 10.1186/s12929-017-0318-z

40 Volk SW and Theoret C: Translating stem cell therapies: The role of companion animals in regenerative medicine. Wound Rep Reg 21: 382-394, 2013. PMID: 23627495. DOI: 10.1111/wrr.12044

41 Cherubino M, Rubin JP, Miljkovic N, Kelmendi-Doko A and Marra KG: Adipose-derived stem cells for wound healing applications. Ann Plast Surg 66: 210-215, 2011. PMID: 21200308. DOI: 10.1097/SAP.0b013e3181e6d06c

42 Upchurch DA, Renberg WC, Roush JK, Miliken GA and Weiss ML: Effects of administration of adipose-derived stromal vascular fraction and platelet-rich plasma to dogs with osteoarthritis of the hip joints. Am J Res 77: 940-951, 2016. PMID: 27580105. DOI: 10.2460/ajvr.77.9.940

43 Kriston-Pal E, Czibula A, Gyuris Z, Balka G, Seregi A, Sükösd F, Süth M, Kiss-Tóth E, Haracska L, Uher F and Monostori E: Characterization and therapeutic application of canine adipose mesenchymal stem cells to treat elbow osteoarthritis. Can J Vet Res 81: 73-78, 2017. PMID: 28197017.
44 Beane OS and Darling EM: Isolation, characterization and differentiation of stem cells for cartilage regeneration. Ann Biomed Eng 40: 2079-2097, 2012. PMID: 22907257. DOI: 10.1007/s10439-012-0639-8

45 Szustka A and Rogalińska M: Potential application for stem cells in regenerative medicine and transplantology. Postepy Biochem 63: 142-150, 2017. PMID: 28689382.

46 Ramakrishnan S, Anand V and Roy S: Vascular Endothelial growth factor signalling in hypoxia and Inflammation. $J$ Neuroimmune Pharmacol 9: 142-160, 2014. PMID: 24610033. DOI: $10.1007 / \mathrm{s} 11481-014-9531-7$

47 Ruiz de Almaodovar C, lambrechts D, Mazzone $M$ and Carmeliet P: Role and therapeutic potential of VEGF in the nervous system. Physiol Rev 89: 607-648, 2009. PMID: 19342615. DOI: $10.1152 /$ physrev.00031.2008
Received March 15, 2019

Revised June 20, 2019

Accepted June 24, 2019 